\title{
Antibacterial Activity Assay From Sintrong Leaf Crassocephalum crepidiodies Against Staphylococcus aureus Bacteria
}

\section{Uji Aktivitas Antibakteri Ekstrak Daun Sintrong (Crassocephalum crepidiodies) Terhadap Bakteri Staphylococcus aureus}

\author{
Siti Maimunah*, Harji Anggia Pratama, Ulfayani Mayasari \\ Program Studi Farmasi, Fakultas Farmasi dan Ilmu Kesehatan Universitas Sari Mutiara \\ Indonesia, Medan. Jalan Kapten Muslim N0. 79 Medan 20123. \\ *Email : siti_mai09@yahoo.com
}

Diterima 04 Maret 2020 dan Disetujui 31 Maret 2020

\begin{abstract}
Abstrak
Sintrong (Crassocephalum crepidioides) adalah sejenis tumbuhan suku Asteraceae. Kegunaannya sebagai bahan obat tradisional seperti mengatasi gangguan perut, sakit kepala, dan luka bekas bisul biasa dilakukan oleh masyarakat Medan. Penelitian ini bertujuan untuk mengetahui spesifikasi tentang karakteristik, golongan senyawa kimia dan aktivitas antibakteri ekstrak etanol daun Sintrong (Crassocephalum crepidioides) terhadap bakteri Staphylococcus aureus. Sampel yang digunakan adalah daun sintrong (Crassocephalum crepidioides) yang diambil dari desa Mupakat Jadi, Kecamatan Bukit, Kabupaten Bener Meriah. Metode penelitian ini dilakukan secara purposif dengan tahapan penelitian yaitu pengambilan bahan tumbuhan, identifikasi, pembuatan simplisia, karakterisasi simplisia, skrining fitokimia, pembuatan ekstrak dan pengujian aktivitas antibakteri. Pengujian aktivitas antibakteri dengan metode difusi menggunakan kertas cakram. Parameter yang diamati yaitu diameter zona hambat pertumbuhan bakteri Staphylococcus aureus di area kertas cakram. Hasil uji aktivitas antibakteri memperlihatkan tingkat efektivitas sedang, dengan konsentrasi 2,5 $\mathrm{mg} / \mathrm{ml}$ memberikan diameter daerah hambat $(9,5 \mathrm{~mm})$ terhadap bakteri Staphylococcus aureus, konsentrasi $5 \mathrm{mg} / \mathrm{ml}$ memberikan diameter daerah hambat $(10,7 \mathrm{~mm})$ terhadap Staphylococcus aureus, konsentrasi $7,5 \mathrm{mg} / \mathrm{ml}$ memberikan diameter daerah hambat $(10,9 \mathrm{~mm})$ terhadap Staphylococcus aureus, dan konsentrasi $10 \mathrm{mg} / \mathrm{ml}$ memberikan diameter daerah hambat $(11,5 \mathrm{~mm})$ terhadap Staphylococcus aureus.
\end{abstract}

Kata kunci: Crassocephalum crepidioides, Antibakteri, Staphylococcus aureus, daerah hambat

\begin{abstract}
Sintrong (Crassocephalum crepidioides) is Asteraceae's family plant. In Medan in addition used as a vegetable, sintrong leaves also be used as traditional medicine; among them to cope with stomach disorders, headache, and ulcer scars. The purpose of this research was spesification about characteristic, determination of chemical compounds group and antibacterial activity of ethanol extract, $n$-heksana fraction, ethylacetate fraction and water fraction of sintrong leaves against Staphylococcus aureus. The sample used was Sintrong (C. crepidioides) taken from Mupakat Jadi Village, Bukit Subdistrict, Bener Meriah districts. This research purposive stages, namely materials plant, identification, preparation and characterization simplisia, determination the class of chemical compounds of simplex, preparation extract and antibacterial activity tested. Test of antibacterial activity by agar diffusion method used paper disc. Parameters measured were inhibition zone of S. aureus. Antibacterial activity test results shows are effectivity, with a concentration of $2,5 \mathrm{mg} / \mathrm{ml}$ provides inhibition area diameter $(9,5 \mathrm{~mm})$ against $\mathrm{S}$. aureus bacteria, a concentration of $5 \mathrm{mg} / \mathrm{ml}$ provides inhibition area diameter $(10,7 \mathrm{~mm})$ to $\mathrm{S}$. aureus, a concentration of $7,5 \mathrm{mg} / \mathrm{ml}$ provides inhibition area diameter $(10,9 \mathrm{~mm})$ to $\mathrm{S}$. aureus, and a concentration $10 \mathrm{mg} / \mathrm{ml}$ provides inhibition area diameter $(11,5 \mathrm{~mm})$ to $\mathrm{S}$.
\end{abstract}


aureus.

Keywords: Crassocephalum crepidioides, Antibacterial, Staphylococcus aureus, Inhibition zone

\section{PENDAHULUAN}

Sintrong (Crassocephalum crepidioides) merupakan tumbuhan anggota suku Asteracae umumnya tumbuh liar sebagai gulma pada tanaman perkebunan, lahan terlantar atau di tepi jalan pada ketinggian $200 \mathrm{~m}$ dpl (Dalimartha, 2006). Di Afrika, daun sintrong tidak hanya dikonsumsi sebagai makanan tetapi juga dimanfaatkan sebagai obat tradisional untuk mengatasi gangguan perut, luka, sakit kepala, dan gatal-gatal (Grubben dan Denton, 2004). Di Indonesia sendiri, daun sintrong pertama kali dijumpai di Medan sekitar tahun 1926. Dari Medan kemudian menyebar ke seluruh penjuru nusantara. Pertumbuhan tanaman sintrong makin subur di daerah lembab hingga ketinggian $2.500 \mathrm{~m}$ dpl. Tidak sedikit yang memanfaatkan daun Sintrong untuk pakan ternak, daun Sintrong juga sebagai obat kanker yang sudah popular (Soerjani et al, 1987).

Selain dapat digunakan sebagai lalapan, daun Sintrong digunakan sebagi obat bisul (Kusdianti, 2008). Secara tradisional daun Sintrong juga digunakan sebagai nutraceutikal dan juga dipercaya bisa mengobati berbagai macam penyakit, seperti untuk mengatasi gangguan pencernaan, sakit kepala, sakit perut, mengobati luka bekas bisul, antelmentik, antiinflamasi, antidiabetes, dan antimalaria (Adjatin, 2013).

Staphylococcus aureus merupakan bakteri gram positif berbentuk bulat berdiameter 0,7$1,2 \mu \mathrm{m}$, tersusun dalam kelompok-kelompok yang tidak teratur seperti buah anggur, fakultatif anaerob, tidak membentuk spora, dan tidak bergerak. Bakteri ini tumbuh pada suhu optimum $37^{\circ} \mathrm{C}$, tetapi membentuk pigmen paling baik pada suhu kamar $\left(20-25^{\circ} \mathrm{C}\right)$. Koloni pada perbenihan media MSA (Manito Salt Agar) padat berwarna abu-abu sampai kuning keemasan, berbentuk bundar, halus, menonjol, dan berkilau. Lebih dari $90 \%$ isolat klinik menghasilkan Staphylococcus aureus yang mempunyai kapsul polisakarida atau selaput tipis yang berperan dalam virulensi bakteri (Jawetz, 1995).

Dengan ini dilakukan penelitian uji aktivitas antibakteri ekstrak etanol dan fraksi daun sintrong (Crassocephalum crepidioides) terhadap bakteri Staphylococcus aureus yang mencakup pemeriksaan karakteristik simplisia, golongan senyawa kimia, serta aktivitas antibakteri ekstrak daun sintrong (Crassocephalum crepidioides) terhadap jenis bakteri gram positif yaitu Staphylococcus aureus.

\section{METODE}

\section{Waktu dan Tempat}

Penelitian ini dilakukan pada bulan Juni sampai September 2018 di Laboratorium Mikrobiologi, Fakultas Farmasi, Universitas Sari Mutiara Indonesia. Medan.

\section{Alat dan Bahan}

Adapun Alat yang digunakan dalam penelitian ini adalah alat-alat gelas, biosafety cabinet (Astec HLF 1200 L), blender (philips), desikator, inkubator (memmert), kompor (sharp), lemari pendingin (toshiba), oven pengering, mikro pipet (Eppendrof), Bunsen, pipet volume $100 \mathrm{ml}$ merek pyrex, pipet mikro $10 \mu \mathrm{m}$, neraca analitik 1000 gr (metler AE 200), autoklaf (Fison), oven listrik (Fischer scientific), pecadang kertas, penguap putar (Haake D), tanur (Gallenkomp), vortex (Health H-MV-300), rotary vacum evaporator. Dan bahan yang 
digunakan dalam penelitian ini adalah ekstrak daun sintrong (Crassocephalum crepidioides), media Nutrien Agar (NA), suspensi Mc.Farland, bakteri Staphylococcus aureus, akuades, etanol $96 \%$.

\section{Prosedur Penelitian}

\section{Pengolahan Tumbuhan Daun Sintrong}

Bahan baku daun Sintrong yang masih segar dikumpulkan, disortasi basah, dicuci bersih di bawah air yang mengalir, ditiriskan, dan ditimbang berat basahnya. Daun Sintrong selanjutnya dikeringkan di lemari pengering hingga kering dengan temperatur $50-60^{\circ} \mathrm{C}$, kemudian disortasi selama tiga hari kering dan ditimbang berat kering nya. Simplisia kering dihaluskan dengan menggunakan blender, sehingga diperoleh serbuk daun Sintrong (Tresna, 2015)

\section{Pembuatan Ekstrak Dilakukan Dengan Ekstraksi Bertingkat}

Pembuatan ekstrak daun Sintrong dilakukan dengan cara maserasi menggunakan pelarut n-heksana, etil asetat, dan etanol 96\%. Cara pembuatan ekstrak adalah sebanyak 200 gr serbuk simplisia dimasukkan ke dalam bejana. Serbuk simplisia dimaserasi dengan campuran etanol $96 \%$ sebanyak $500 \mathrm{ml}$, dibiarkan pada suhu kamar selama 3 jam, terlindung dari cahaya sambil sekali-kali diaduk. Selanjutnya, hasil yang diperoleh disaring, kemudian ditampung ke dalam botol. Ekstrak cair kemudian dipekatkan menggunakan rotary vacum evaporator. Larutan yang diperoleh diuapkan di cawan penguap selama 2 hari. Proses ini bertujuan untuk menguapkan etanol sehingga diperoleh ekstrak yang kental dari daun Sintrong

\section{Pembuatan Stok Kultur Bakteri}

Masing-masing sebanyak 1 ose biakkan murni bakteri Staphylococcus aureus, digoreskan dengan metode sinambung pada permukaan Nutrien Agar (NA) miring, ditutup tabung reaksi dengan kapas, kemudian diinkubasi selama $18-24$ jam pada suhu $37^{\circ} \mathrm{C}$.

\section{Uji Skrining Fitokimia}

Skrining fitokimia simplisia meliputi pemeriksaan senyawa golongan alkaloida, glikosida, steroid/triterpenoida, flavonoid, saponin, dan tanin.

\section{Pemeriksaan Alkaloida}

Serbuk simplisia ditimbang sebanyak 0,5 g kemudian dimasukkan ke dalam tabung reaksi lalu ditambahkan $1 \mathrm{ml}$ asam klorida $2 \mathrm{~N}$ dan $9 \mathrm{ml}$ air suling, dipanaskan di atas penangas air selama 2 menit, didinginkan lalu disaring (Depkes RI, 1995). Filtrat yang dipakai untuk percobaan sebagai berikut:

1. Filtrat sebanyak 3 tetes ditambahkan 2 tetes larutan Mayer akan terbentuk endapan bewarna putih atau kuning

2. Filtrat sebanyak 3 tetes ditambahkan 2 tetes larutan Bouchardat akan terbentuk endapan bewarna cokelat hitam

3. Filtrat sebanyak 3 tetes ditambahkan 2 tetes larutan Dragendorff akan terbentuk endapan bewarna merah atau jingga.

Alkaloid dinyatakan positif jika terjadi endapan atau paling sedikit 2 atau 3 dari percobaan di atas. Perlakuan yang sama dilakukan terhadap daun Sintrong.

\section{Pemeriksaan Flavonoida}


Sebanyak 10 gr serbuk simplisia dimasukkan ke dalam tabung reaksi lalu ditambahkan $10 \mathrm{ml}$ air panas, dididihkan selama 5 menit dan disaring dalam_keadaan panas, ke dalam $5 \mathrm{ml}$ filtrat ditambahkan $0,1 \mathrm{~g}$ serbuk magnesium dan $1 \mathrm{ml}$ asam klorida pekat dan $2 \mathrm{ml}$ amil alkohol, di kocok dan dibiarkan memisah.

Flavonoida positif jika terjadi warna merah atau kuning atau jingga pada lapisan amil alkohol. Perlakuan yang sama juga dilakukan terhadap serbuk simplisia daun Sintrong (Farnsword, 1966).

\section{Pemeriksaan Glikosida}

Serbuk simplisia ditimbang sebanyak 3 gr kemudian disaring dengan $30 \mathrm{ml}$ campuran 7 bagian volume etanol 96\% dan 3 bagian volume air suling, selanjutnya ditambahkan $10 \mathrm{ml}$ HCL $2 \mathrm{~N}$, direfluks selama 10 menit, didinginkan dan disaring. Pada $30 \mathrm{ml}$ filtrat ditambahkan $25 \mathrm{ml}$ air suling dan $25 \mathrm{ml}$ timbal (II) asetat $0,4 \mathrm{M}$, dikocok, didiamkan selama 5 menit lalu disaring. Filtrat disaring sebanyak 3 kali, tiap dengan $20 \mathrm{ml}$ campuran 3 bagian volume kloroform dan 2 bagian isopropanol. Diambil lapisan air kemudian ditambahkan 2 $\mathrm{ml}$ air dan 5 tetes pereaksi Molish, ditambahkan hati-hati $2 \mathrm{ml}$ asam sulfat pekat terbentuk cincin ungu pada batas kedua cairan menunjukkan adanya gula. Perlakuan yang_sama juga dilakukan terhadap serbuk simplisia daun sintrong (Depkes RI, 1995).

\section{Pemeriksaan Tanin}

Sebanyak 0,5 gr serbuk simplisia disari dengan $10 \mathrm{ml}$ air suling, disaring_lalu filtratnya diencerkan dengan air suling sampai tidak berwarna. Diambil 2 ml_larutan lalu ditambahkan 1 sampai 2 tetes pereaksi besi (III) klorida $1 \%$. Terbentuknya warna biru atau hijau kehitaman menunjukkan adanya tanin. Perlakuan yang sama juga dilakukan terhadap serbuk simplisia daun Sintrong (Depkes RI, 1995).

\section{Pemeriksaan Saponin}

Sebanyak 0,5 gr serbuk simplisia dimasukkan ke dalam tabung reaksi dan ditambahkan $10 \mathrm{ml}$ air suling panas, didinginkan kemudian dikocok kuat-kuat selama 10 detik, timbul busa yang mantap tidak kurang dari 10 menit setinggi $1-10 \mathrm{~cm}$. Ditambahkan 1 tetes larutan asam klorida $2 \mathrm{~N}$, bila buih tidak hilang menunjukkan adanya saponin. Perlakuan yang sama juga dilakukan terhadap serbuk simplisia daun sintrong (Depkes RI, 1995).

\section{Pemeriksaan Steroid/Triterpenoida}

Sebanyak 1 gr serbuk simplisia dimaserasi dengan $20 \mathrm{ml} n$-heksana selama 2 jam, lalu disaring. Filtrat diuapkan dalam cawan penguap. Pada sisa dalam cawan penguap ditambahkan 2 tetes asam asetat anhidrida dan 1 tetes asam sulfat pekat. Timbul warna ungu atau merah kemudian berubah menjadi hijau biru menunjukkan adanya steroidatriterpenoida. Perlakuan yang sama juga dilakukan terhadap serbuk simplisia daun sintrong (Harbone, 1987).

\section{Uji Aktivitas Antibakteri}

Pengujian aktivitas antibakteri dari ekstrak kental daun sintrong (Crassocephalum crepidiodies) terhadap bakteri Staphylococcus aureus dilakukan dengan metode difusi agar menggunakan antibakteri kloramfenikol sebagai pembanding, yang telah ditumbuhkan pada media NA dengan pemberian 4 varian konsentrasi yaitu 2,5\%, 5\%,7,5\%, dan $10 \%$. 
Aktivitas antibakteri ditentukan dengan menggukur zona hambat yang terbentuk di_sekitar kertas cakram. Setelah diperoleh hasil pengujian aktivitas antibakteri, dipilih ekstrak dengan aktivitas antibakteri terbaik yang dapat menghambat pertumbuhan bakteri uji, yaitu Staphylococcus aureus terhadap ekstrak daun sintrong (Crassocephalum crepidiodies). dilakukan uji KHM untuk menentukan konsentrasi terkecil yang memiliki aktivitas antibakteri dari ekstrak tersebut.

\section{Analisa Data}

\section{Hasil Ekstraksi Daun Sintrong}

Penelitian yang dilakukan dengan menggunakan daun Sintrong yang segar sebanyak $5 \mathrm{~kg}$ dan berat daun kering 200 gr. Simplisia daun Sintrong (Crassocephalum crepidiodies) sebanyak 200 gr yang dimaserasi dengan 2 liter etanol 96\% diperoleh ekstrak kental 32,56 gr, warna ekstrak kental hijau tua pada konsentrasi rendaman $10 \%$.

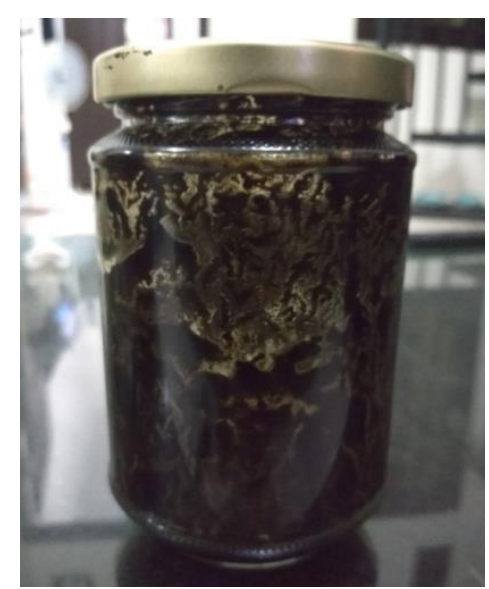

Gambar 1. Hasil Ekstrak Daun Sintrong (Crassocephalum crepidiodies)

\section{Hasil Skrining Fitokimia Ekstrak Daun Sintrong}

Hasil pemeriksaan skrining fitokimia serbuk simplisia, ekstrak daun sintrong terlihat pada tabel 1. berikut ini :

Tabel 1. Hasil Skrining Fitokimia

\begin{tabular}{llccccc}
\hline No & Golongan senyawa & \multicolumn{5}{c}{ Hasil } \\
\cline { 3 - 7 } & & Serbuk & $\begin{array}{c}\text { Ekstrak } \\
\text { etanol }\end{array}$ & $\begin{array}{c}\text { Fraksi } \\
\text { n-heksana }\end{array}$ & $\begin{array}{c}\text { Fraksi } \\
\text { n-etil asetat }\end{array}$ & $\begin{array}{c}\text { Fraksi } \\
\text { air }\end{array}$ \\
\hline 1 & Alkaloid & - & - & - & - & - \\
2 & Flavonoid & + & + & - & + & + \\
3 & Glikosida & + & + & - & + & + \\
4 & Tanin & + & + & - & + & - \\
5 & Saponin & - & - & - & - & - \\
6 & Steroid/triterpenoid & + & + & + & - & -
\end{tabular}

Keterangan : $(+)$ positif $=$ mengandung golongan senyawa; $(-)$ negatif $=$ tidak mengandung golongan senyawa

Pada serbuk simplisia, ekstrak etanol daun Sintrong setelah ditambahkan serbuk $\mathrm{Mg}$ dan asam klorida, akan terbentuk warna jingga kemerahan, menunjukkan adanya senyawa 
flavonoid. Penambahan pereaksi Molish dan asam sulfat pekat akan terbentuk cincin berwarna ungu pada batas cairan menunjukkan adanya senyawa glikosida. Penambahan $\mathrm{FeCl} 3$ 1\% memberikan warna hijau kehitaman yang menunjukkan adanya senyawa tanin. Penambahan pereaksi Liebermann-Bauchard memberikan warna merah ungu dan hijau biru, yaitu adanya steroid/triterpenoid.

\section{Uji Aktivitas Antibakteri}

Hasil uji aktivitas antibakteri (Table 1) menunjukkan bahwa terdapat zona hambat pada hari pertama dengan konsentrasi 2,5\% (1,6 mm), 5\% (1,8 mm), 7,5\% (1,9 mm), dan 10\% (2 $\mathrm{mm})$. Kloramfenikol sebagai kontrol positif memiliki zona hambat sebesar $25,4 \mathrm{~mm}$ sehingga kloramfenikol dikategorikan memiliki daya hambat yang sangat kuat. Kloramfenikol memiliki sifat bakteriostatik karena mengganggu proses sintesis protein bakteri.

Pada hari ke-2 menunjukan bahwa terdapat zona hambat pada konsentrasi $2,5 \%, 5 \%, 7,5 \%$ dan $10 \%$ di sekitar kertas cakram yaitu dengan rata-rata 2,5\% (1,8 mm), 5\% (2,6 mm). 7,5\% (2,8 mm), dan 10\% (3 mm), dan pada hari ke-3 terdapat zona hambat di sekitar kertas cakram dengan rata-rata 2,5\% (5,8 $\mathrm{mm}), 5 \%(6,3 \mathrm{~mm}), 7,5 \%(6,4 \mathrm{~mm})$, dan $10 \%$ (6,6 mm). Antibakteri memiiki 3 mekanisme kerja. Mekanisme kerja yang pertama adalah dengan menghambat biosintesis dinding sel bakteri. Mekanisme yang kedua adalah dengan meningkatkan permeabilitas membran sitoplasma bakteri. Mekanisme kerja yang ketiga adalah dengan mengganggu sintesis protein normal bakteri seperti kloramfenikol (Mutschler, 1986). Selain faktor konsentrasi, jenis bahan antimikroba juga menentukan kemampuan menghambatan pertumbuhan bakteri, dalam penelitian ini konsentrasi dan lamanya inkubasi sangat mempengaruhi zona hambat bakteri Staphylococcus aureus. Pada kontrol positif zona hambat pada kertas cakram semakin membesar pada hari ke-3 dapat dilihat pada tabel 2 .

Tabel 2. Nilai Rata- Rata Diameter Zona Hambat Per Hari

\begin{tabular}{cccc}
\hline \multirow{2}{*}{ Konsentrasi } & \multicolumn{3}{c}{ Waktu Pengamatan } \\
\cline { 2 - 4 } & Hari ke-1 $(\mathrm{mm})$ & Hari ke-2 $(\mathrm{mm})$ & Hari ke-3 $(\mathrm{mm})$ \\
\hline $2,5 \%$ & 1,6 & 1,9 & 5,8 \\
$5 \%$ & 1,8 & 2,6 & 6,3 \\
$7,5 \%$ & 1,9 & 2,8 & 6,4 \\
$10 \%$ & 2 & 3 & 6,5 \\
Kontrol positif & 25,4 & 25,5 & 27,2 \\
(Kloramfenikol) & & & \\
\hline
\end{tabular}

Aktivitas antibakteri ekstrak daun sintrong (Crassocephalum crepidiodies) setelah diamati pada 48 jam bakteri tidak tumbuh pada daerah hambat. Hal ini menunjukkan bahwa ekstrak daun sintrong dapat membunuh bakteri. Berdasarkan sifat toksisitas selektifnya, senyawa antibakteri memiliki efek bakteriostatik, bakteriosida, dan bakteriolitik terhadap pertumbuhan mikroba. Efek bakteriostatik akan mematikan sel bakteri tersebut, namun tidak terjadi lisis sel, hal ini akan menyebabkan jumlah sel yang tumbuh menurun dan menghambat terjadinya sintesis dinding sel (Madigan. 2005). Dari penjelasan tersebut bahwa ekstrak daun sintrong bersifat bakteriostatik, bakteriosida, dan bakteriolitik yang memiliki 
aktivitas membunuh bakteri terhadap Staphylococcus aureus. Hasil pengujiam aktivitas antibakteri ekstrak daun sintrong terhadap bakteri Staphylococcus aureus dapat dilihat pada gambar 2 .
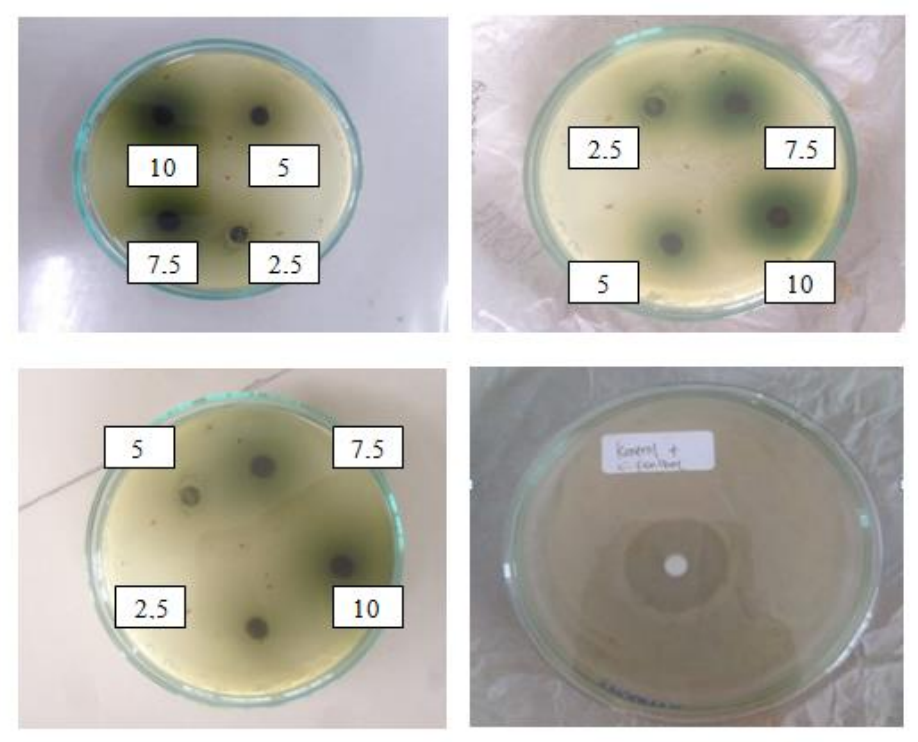

Gambar 2. Hasil Pengujian Aktivitas Antibakteri Ekstrak Daun Sintrong Terhadap Bakteri Staphylococcus aureus (a) Pengulangan I; (b) Pengulangan II; (c) Pengulangan III; (d) Kontrol + (Kloramfenikol).

Efek antibakteri yang paling baik terlihat pada konsentrasi ekstrak $10 \%$ pada bakteri Staphylococcus aureus.Perubahan rata-rata diameter zona hambat pertumbuhan bakteri dapat dilihat pada tabel 2. Menurut David \& Stout (1971), jika diameter zona hambat $5 \mathrm{~mm}$ atau kurang maka aktivitas penghambatan dikategorikan lemah, diameter zona hambat 6-10 $\mathrm{mm}$ maka dikategorikan sedang, diameter $21 \mathrm{~mm}$ atau lebih maka aktivitas penghambatan dikategorikan sangat kuat. Jadi pada penelitian ini menunjukkan konsentrasi 2,5\% (5,8 $\mathrm{mm}), 5 \%(6,3 \mathrm{~mm}), 7,5 \%(6,4 \mathrm{~mm}), 10 \%(6,5 \mathrm{~mm})$ dikategorikan zona hambat sedang. Namun, yang paling efektif adalah pada konsentrasi 10\%. Kloramfenikol sebagai kontrol positif berbeda secara nyata dengan perlakuan ekstrak daun sintrong dan memiliki nilai zona hambat paling besar. Kloramfenikol memiliki diameter zona hambat sebesar 27,2 $\mathrm{mm}$ sehingga dikategorikan sangat kuat. Senyawa penghambat antimikroba pada kloramfenikol akan menyebabkan Staphylococcus aureus salah membaca kode pada mRNA oleh tRNA (hambatan translasi dan transkripsi bahan genetik (Jawetz et al, 1996). Pemilihan kloramfenikol sebagai kontrol positif dikarenakan kloramfenikol merupakan antibakteri pertama yang berspektrum luas, yang aktif terhadap bakteri gram positif diantaranya adalah bakteri Staphylococcus aureus dengan mekanisme kerja menghambat sintesis protein dan bersifat bakteriostatik (Sweetman, 2009).

\section{KESIMPULAN}

Dari penelitian ini dapat diperoleh kesimpulan bahwa : (1) Ekstrak daun sintrong (Crassocephalum crepidiodies) memiliki aktivitas antibakteri terhadap bakteri Staphylococcus aureus. (2) Pada Konsentrasi ekstrak sintrong 10\% merupakan konsentrasi efektif untuk menghambat bakteri Staphylococcus aureus dengan kemampuan menghambat sebesar 6,5 mm. 


\section{DAFTAR PUSTAKA}

Abdul, R. 2007. Kimia Farmasi Analisis. Yogyakarta: Pustaka Pelajar.

Adam, M., R. Moss. 1995. Food Microbiology. The Royal Society of Chemistry. Cambridge. London.

Adjatin. 2013. Phytochemical screening and toxicity studies of Crassocephalum crepidioides (Benth.) S. moore Consumed as vegetable in Benin. Volume 2.Int.J.Curr.microbiol.App.Sci, 2(8): $1-13$.

Basset, J. 1994. Buku Ajar Voage Kimia Analisis Kuantitatif Anorganik. Jakarta: Penerbit Buku Kedokteran egc.

Dalimartha, S. 2006. Atlas Tumbuhan Obat Indonesia Jilid 4. Jakarta : Puspa Swara. pp. iv.

Departemen Kesehatan RI. 2000. Parameter Standar Umum Ekstrak Tumbuhan Obat. Direktorat Jendral Pengawasan Obat dan Makanan Direktorat Pengawasan Obat Tradisional. Jakarta. 17, 31-32.

Djauhariya, E., Hernani. 2004. Gulma Berkhasiat Obat. Cetakan I. Jakarta: Swadaya.

Gaty, S., Endah. 2015. Uji Aktivitas Antibakteri Daun Kenikir (Cosmos caudatus Kunth.) dan Daun Sintrong (Crassocephalum crepidiodies (Benth.) S. Moore.) terhadap Bakteri Staphylococcus aureus dan Pseudomonas aeruginosa. Jurnal Prosiding Penelitian SpeSIA Unisba. Hal 423.

Grubben, G J H., OA Denton. 2004. Plant Resources of Tropical Africa 2. Backhuys Publisher. Wageningen.

Hidayat, S., RM Napitupulu. 2015. Kitab Tumbuhan Obat. Jakarta

Irianto, K. 2006. Mikrobiologi mengguak dunia mikroorganisme. Jilid I. Bandung : CV. Rama Widya. Hal 56-58, 147, 148.

Jay, J M. 2000. Modern Food Microbiology Sixth Edition. Maryland: Aspen Publishers.

Jawetz, E., JL Menick., EA Adelberg. 1996. Mikrobiologi Kedokteran. Edisi ke-20. Hal 4650. Nugroho E. Maulany RF. Penerjemah. Jakarta: Buku Kedokteran EGC.

Kusdianti. 2008. Tumbuhan Obat Di Lengkojero Situ Lembang. Bandung. Fakultas Pendidikan Matematika dan Ilmu Pengetahuan Alam. Universitas Pendidikan Indonesia.

Lay, B. 1994. Analisis Mikroba di Laboratorium. Jakarta : Rajawali.

Madigan, M. 2005. Brock Biology of Microorganisme. London: PrenticeHall. Hal :753.

Mutschler, E. 1986. Dinamuka Obat Farmakologi dan Toksologi. Edisi ke-5. ITB. Bandung.

Oxoid. 2013. Nutrient Agar and Nutriend Browlh. England: Oxolid LTD. 
Pelczar, M J., E C S Chan., M.F Pelczar. 1988. Dasar-Dasar Mikrobiologi Jilid 2, (diterjemahkan oleh Hadioetomo, R.S. dkk.). Jakarta: Penerbit Universitas Indonesia.

Pratiwi, T S. 2008. Mikrobiologi Farmasi. Jakarta: Erlangga.

Septianingrum, ER., R H F Faradilla., R Ekafitri., S Murtin., D Perwatasari. 2009. Kadar fenol dan aktivitas antioksidan pada teh hijau dan teh hitam komersial. Koleksi artikel PKM Institut Pertanian Bogor. Bogor. https://repository.ipb.ac.id/handle/123456789/19950, diakses pada 4 Maret 2020

Supardi., Sukamto. 1999. Mikrobiologi, Pengolahan dan Keamanan Pangan. Jakarta: Alumni.

Soerjani, M., A J G H Kostermans., G Tjitrosoepomo. 1987. Weeds of Rice in Indonesia. Balai Pustaka. Jakarta. p. 72-73.

Sweetman, C S. 2009. Martindale: The Complete Drug Reference. Edisi 36. London: Pharmaceutical Press. 